\title{
An Empirical Research on the Funds Managers' Skill and Accrual Quality Risk Premium: The Evidence from China
}

\author{
Qian Yang \\ Management School, Jinan University, Guangzhou, China \\ Email: 15626091105@163.com
}

How to cite this paper: Yang, Q. (2018) An Empirical Research on the Funds Managers' Skill and Accrual Quality Risk Premium: The Evidence from China. Open Journal of Business and Management, 6, 373-381.

https://doi.org/10.4236/ojbm.2018.62027

Received: March 23, 2018

Accepted: April 23, 2018

Published: April 26, 2018

Copyright $\odot 2018$ by author and Scientific Research Publishing Inc. This work is licensed under the Creative Commons Attribution International License (CC BY 4.0).

http://creativecommons.org/licenses/by/4.0/

\begin{abstract}
This paper explores the impact of accrual quality information on fund investment decisions, and examines whether fund managers can use the stock's accrual quality information to obtain excess returns, and the difference in fund manager's skill to influence the extent of the fund's excess returns. This paper uses the annual observations of 2851 Chinese funds, from 2005 to 2016 to analyze the fund manager's stock investment decision. The results show that in China capital market, there is a risk premium for accrual quality, and fund managers can obtain excess returns through selecting stocks with poor accrual quality. And fund managers with better skill, can obtain more excess returns.
\end{abstract}

\section{Keywords}

Accrual Quality, Excess Return, Skill

\section{Introduction}

Mutual fund market in China has seen huge changes since the government proposed to develop institutional investors in 2000. At the end of 2017, the number of mutual funds in China reached 3168. As Chinese capital markets mature, investors have gradually become more rational and specialized in selecting funds. The fierce market competition environment requires that fund managers have excellent asset management capabilities, which can create good performance and pursue greater profits. As a result, the issue of fund managers' ability to select stocks has become more and more important.

According to the traditional capital asset pricing model, investors mainly calculate the investment rate of return based on the valuation of the future cash 
flow of the securities and make investment decisions. As a professional investor, the fund manager will collect various information when selecting stocks, and will also use the accounting information from financial statements published by the listed company to evaluate them.

Based on the information risk theory, poor accounting information (such as the earning quality) will undermine the cooperative relationship between the company and investors in the capital investment decision, resulting in information risk. When investors anticipate this risk, they will demand a higher risk premium or return on investment (Leuz \& Verrecchia, 2004) [1]. And the portion of excess earnings which can be explained by earnings quality, is called the risk premium of earning quality. Therefore, based on the above research, this article examines whether the fund manager can use the earnings quality information to obtain excess returns, and studies the factors affecting the fund manager's investment selection and the ability of the fund manager to select shares.

Previous studies have disagreements about the existence of earning quality risk premium. Some studies show that fund managers prefer to invest good earning quality to avoid fundamental risk. Ali et al. (2008) [2] used actively managed mutual funds traded on the US fund market from 1984 to 2003 as a sample, to examine whether mutual funds can use investment accruals to make investment portfolios and earn excess return. The results of the study show that only a few mutual funds use accounting accrual strategies. And this paper start by providing evidence for the conjecture that fund managers also invest in stocks with relatively worse earning quality.

Then, following Francis et al. (2005) this paper calculate the AQ and construct $\mathrm{AQ}$ risk factor, and add the AQ risk factor in the CAPM model, Fama-French's three-factor model (FF3) and five-factor model (FF5), to test the AQ risk factor can explain the excess return.

To provide evidence that Chinese fund managers have stock-selecting ability, and high skilled managers can gain more accrual quality risk premium (AQ premium). This paper examines differences between high skilled fund managers and low skilled managers. Managers' skill is estimated by Amihud and Goyenko (2013) [3] measure, calculating the $\mathrm{R}^{2}$ is from regression of mutual fund returns on either FF3 or FF5, where a lower $\mathrm{R}^{2}$ indicates a greater extent of active portfolio management.

There are two innovations in this paper. Firstly, from the perspective of China's research status, the focus of academic circles is mainly on the role of earnings quality in corporate governance, and there is less research on the information risks represented by earnings quality; secondly, the past The study mainly considers the economic implications of accounting information such as earnings quality from the stock level. This paper further investigates whether fund managers in China use earnings quality information to perform portfolio asset allocation and the impact of fund managers' own investment skills on their use of earnings information. This will allow us to understand more fully the economic 
consequences of earnings quality in the Chinese capital market, and to expand and improve the fund investment professional abilities and other related research.

The rest of this paper is organized as follows. Section 2 contains literature review and formulates predictions. Section 3 introduces the variables and models will be used in this article, and discus the sample selection. Section 4 provides the empirical results. Section 5 concludes.

\section{Literature Review and Empirical Prediction}

\subsection{Mutual Fund Performance and Accrual Quality}

The earning is an important indicator to evaluate company's performance, and it is also one of the financial indicators which is most concerned with empirical accounting research. Earnings quality, as one of the elements of information, assists the effective operation of the capital market, reflects the degree of correlation between the current earning and future cash flow (Green, 1999). Since the 1960s and the 1970s, academic research on the quality of earnings has gradually increased. A large number of literatures have theoretically and empirically analyzed the value relevance of earnings quality, information content, capital pricing functions, and ability to predict future returns.

According to previous research, that non-discretionary accruals (NDA) and discretionary accruals (DA) have different effects on the cost of capital (Guay et al., 1996; Subramanyam, 1996). To more clearly reflect the impact of earnings quality on capital costs, in this article, this paper use discretionary accrual quality (AQ) to be the agent variable of earning quality.

Previous studies have proved the existence of accrual quality risk premium on stock level. Ogneva (2008) [4] found a significant negative correlation between earnings quality and future stock returns. Francis et al. (2004, 2005) [5] [6] construct a substitution variable $\mathrm{AQfactor}$ for earnings quality, which proved that earnings quality is a risk pricing factor. While many researches have shown fund managers can't earn excess return through selecting worse accrual quality stocks. As Bushee \& Raedy (2006) [7] fund that funds unable to use accrual strategy to profit. This paper tests whether there is an accrual quality risk premium in the Chinese market.

\subsection{Manager's Skill}

Generally, we believe that there is a clear phenomenon of information asymmetry in the securities market. Institutional investors have stronger ability to absorb and interpret corporate information, that is, institutional investors have more information advantages. Grossman and Stiglitz (1980) [8] proposed that any investor can obtain information that others do not know, which is called private information, by paying a certain fee. Dybvig, Philip \& Ross (1985) studied the relationship between information discrepancies and the performance evaluation using the securities market line and found that fund managers with 
information advantages may receive excess returns. Kacperzyk and Seru (2007) [9] also proved that fund managers have more "private information".

Scholars generally believe that fund managers have information advantages and have the ability to select outstanding stocks. Chen et al. (2000) [10] demonstrated the link between fund trading and stock returns to prove that fund managers have the ability to choose stocks. Berk and Green (2004) [11] adopted a mutual fund for active investment as a sample, and the results did not reveal any excess. Revenue, but they believe it cannot be denied that the fund manager's ability exists. Baker et al. (2010) [12] believe that fund managers have the ability to predict stock fundamentals, and that competent fund managers will use this information appropriately when configuring portfolios. Berk and Green (2004) used a mutual fund with active investment as a sample. The research results did not find excess returns, but they believed that the existence of fund manager's competence could not be denied.

\subsection{Empirical Prediction}

Consistent with prior research showing that accrual quality is a risk pricing factor on stock level (Francis et al., 2005). Fund managers have stock selecting ability, and stocks held by fund outperform market benchmarks. This paper assumes that fund managers select stocks with poor $\mathrm{AQ}$, in order to obtain more excess returns. Thus, the first prediction is:

H1: There is an accrual risk premium in China mutual fund market.

Prior research believes that fund managers have information advantages and have the ability to select stocks. While, there are difference in fund managers' ability. Accrual quality is an accounting information, the high skilled fund managers can make better use of the AQ. Based on the above analysis the second prediction is:

H2: In China mutual fund market, high skilled mutual fund managers earn a higher premium than low skilled managers.

\section{Sample Selection and Research Design}

\subsection{Sample}

According to the different portfolio assets, China's mutual funds can be divided into money market funds, bond funds, equity funds and hybrid funds. This article focuses on equity funds and partial stock funds, because they can best represent the skill of fund managers on selecting stock. The other filters as follow: 1) excluding the index funds, because such funds are relatively passive and cannot reflect the ability of fund managers to actively select stocks to make profits; 2) to guarantee the availability of stock-level data. The sample excludes QDII funds and ensures that the funds studied in this paper only invest in China capital market; 3) due to the unstable investment behavior of new-build funds during the opening period, the funds that were established in the year are excluded; 4) funds in sample can obtain over $90 \%$ stocks' characters. 


\subsection{Accrual Quality}

Mutual fund characteristics such as AQ, market value, size, book-to-market, are estimated as weighted averages of stock characteristics, with dollar values of holdings used as weights.

Stocks' AQ is estimated using Kothria (2005) measure, modified Jones model, use the following regression for each year and each industries:

$$
T A_{i t}=\beta_{0}+\beta_{2} *\left(1 / \operatorname{ASSETS}_{i t-1}\right)+\beta_{3} *\left(\Delta R E V_{i}-\Delta R E C_{i}\right)+\beta_{4} * P P E G T_{i t}+\varepsilon_{i t}
$$

where $T A_{i t}$ is firm is total current accruals for year $t, A S S E T S_{i t-1}$ is total assets of stock $i$ for year $t-1, \triangle R E V$ is the one-year change in revenue of stock $i$ for year $t$; $\triangle R E C$ is one-year change in accounts receivable of stock $i$ for year $t, P P E G T_{i t}$ is the value of fixed assets for stock $i$ for year $t$; and $\varepsilon_{i t}$ is the residual of the regression, indicating discretionary accruals. In this paper, the absolute value of $\varepsilon_{i t}$ is used as proxy variable AQ to reflect the stock's earnings quality.

For each fund, the AQ measure is estimated as a weighted-average AQ of stock holdings with dollar values of holdings used as weights. The AQ measure is then used to sort funds into 10 portfolios every month.

\subsection{Fund Managers' Skill}

Previous research has found that fund managers are able to predict fundamental risks, and that portfolio management by fund managers is positively related to funds' future performance. In this paper, the degree of active portfolio management is relative to the Fama-French three (five) factors model.

Managers' skill is estimate using Amihud and Goyenko (2013) [3] measure, by calculating the $\mathrm{R}^{2}$ from a regression of mutual fund returns on common asset pricing factors, where the $\mathrm{R}^{2}$ represents the extent to which the returns can be explained by the risk factor. The low $\mathrm{R}^{2}$ indicates a greater extent of active portfolio management.

\subsection{Fund Excess Return}

The prior research uses the information of fund holdings to interpret and predict the return of fund performance, and examines the fund manager's stock selection ability. Grinblatt and Titman (1989) [13], Ferson and Khang (2002) [14] proposed that the use of the fund's holding equity information to calculate the fund's assumed return rate can better measure the fund manager's stock selection ability than the actual fund return rate.

Based on the above analysis, fund returns are computed as the value weighted average returns on the stock level. And the weights are market value of stocks' hold by funds. Excess return is fund return minus risk-free return. And FF3 (5) return is excess return, which is calculated in FF3 (5) model.

\subsection{AQfactor}

AQfactor is an accrual quality risk factor, and its measure method following 
Francis (2005). Sorting funds into deciles based on AQscore. And AQdecile1 and AQdecile 2 represent the top $20 \%$ of the funds with the best accruals, AQdecile 9 and AQdecile 10 represent the bottom $20 \%$ of the funds with the worst accruals. The AQfactor equals the difference between the average returns of the top 20\% funds and bottom $20 \%$ funds at time $t$. And adds AQfactor to the CAPM FF3 (5) model, to test the AQfactor can explain excess return in fund level.

$$
\begin{gathered}
R_{i, t}-R_{F, t}=\alpha_{i}+\beta_{1 i}\left(R_{M, t}-R_{F, t}\right)+\beta_{2 i} \text { AQfactor }_{t}+\varepsilon_{i, t} \\
R_{i, t}-R_{F, t}=\alpha_{i}+\beta_{1 i}\left(R_{M, t}-R_{F, t}\right)+\beta_{2 i} S M B_{t}+\beta_{3 i} H M L_{t}+\beta_{4 i} \text { AQfactor }_{t}+\varepsilon_{i, t} \\
R_{i, t}-R_{F, t}= \\
\alpha_{i}+\beta_{1 i}\left(R_{M, t}-R_{F, t}\right)+\beta_{2 i} S M B_{t}+\beta_{3 i} H M L_{t} \\
+\beta_{4 i} R M W+\beta_{5 i} C M A+\beta_{6 i} \text { AQfactor }_{t}+\varepsilon_{i, t}
\end{gathered}
$$

where, $R_{i t}$ is fund $i$ 's return for year $\mathrm{t}, R_{F, t}$ is free risk return for year $\mathrm{t}, R_{M, t}$ is the market return for year $t, S M B$ is market value factor for year $t, H M L$ is the book to market factor of time $t, R M W$ is the profitability factor of time $t$, and $C M A$ is the investment model factor. The above data were obtained from the CSMAR database.

\section{Empirical Results}

\subsection{Descriptive Statistics}

Table 1 presents descriptive statistics for the mutual fund sample. This paper divides funds into growth funds, value funds, and equilibrium funds according to funds' investment objectives and investment strategies.

The average size is 20.84 , the average size of the value funds is the largest (21.27); the average size of the growth funds is the smallest (20.76), which is lower than the average size of the funds. The average invest ret is RMB 220.7 million, value funds average investment income is the highest (RMB 289 million). And equilibrium funds is lowest (RMB 114 million), which is far below the average investment income of the funds.

According to Table 1, compared with other investment style funds, value funds have higher returns, growth funds' returns are relatively low, and their fund operating costs are relatively low. Funds' average market value (MVscore) is

Table 1. Descriptive statistics.

\begin{tabular}{ccccc}
\hline & All Funds & Growth & Value & Equilibrium \\
\hline Size (mean) & 20.84 & 20.76 & 21.27 & 20.86 \\
Invest ret (mean) & 220.7 & 210.0 & 288.8 & 114.5 \\
Stock ret (mean) & 197.9 & 189.1 & 257.2 & 94.77 \\
Fees (mean) & 60.08 & 56.31 & 77.59 & 62.54 \\
AQ score (mean) & 0.0567 & 0.0576 & 0.0563 & 0.0554 \\
MV score (mean) & 41865 & 41790 & 42207 & 39044 \\
BM score (mean) & 1.463 & 1.456 & 1.463 & 1.542 \\
\hline
\end{tabular}


RMB 41.865 billion, far higher than the average MV of the stock market (RMB 31.073 billion). Similarly, the BMscore is 1.463 , which is lower than the average BM (1.536) of the stock market. It proves that the company invested by the fund is relatively large, but its book value to market ratio is relatively low. The average earnings quality of the fund, AQscore, is 0.0567 , which is similar to the average of the stock accrual quality (0.0529). Based on investment styles, that value funds have better earnings quality (AQscore), larger company size (MVscore), and lower company growth (BMscore) than growth funds. Which is consistent with the previous study, the growth fund pursued share price while the value fund focused on the long-term benefit distribution of the company.

Size represents the average size of the fund, which is equal the natural logarithm of the net assets of the fund. Invest ret is average fund investment income. Stock ret represents average funds stock investment income. Fees represent the average fund operating expenses, including fund manager management fees and fund custodian fees.

\subsection{Funds Accrual Risk Premium}

This paper adds AQfactor to the CAPM, FF3 (5) model, to test the AQfactor can explain excess return in fund level.

Columns (1), (2) and (3) of Table 2 show the regression results of the CAPM model, the FF3 model and the FF5 model. In order to explain whether the accrual quality is a risk factor, this paper adds the AQfactor as the earnings quality risk factor on the basis of the original model. The results show that after adding the AQfactor in the above three models, the risk factor is significantly at $1 \% \mathrm{lev}$ el, which prove that the accrual quality is a risk pricing factor.

\subsection{Fund Managers' Skill}

To compare AQ premium estimates across funds headed by managers with different skill levels, we sort funds into low-, middle-, and high-skill terciles. And skill is measured as FF3 (5) $\mathrm{R}^{2}$. Table 3 provides time-series averages of portfolio returns for the two-way sorts. Table 3 shows the funds sort by FF3 (5) $R^{2}$. The results show that funds with the best fund managers' ability (skill $=1$ ) all have higher returns than low skill funds. FF3 (5) is excess return calculated by FF3 (5) model. It proves that the better the fund manager's ability, the higher excess return obtained.

This proves the hypothesis 2. In China mutual fund market, compared with poor skilled managers, high skilled mutual fund managers earn a higher accrual premium.

\section{Conclusions}

This paper uses China's mutual fund as sample, to examine the following questions: 1) Whether the fund manager can use the accrual quality to obtain the excess return; 2) The relationship between the fund manager's ability and the 
Table 2. Funds accrual risk premium.

\begin{tabular}{|c|c|c|c|}
\hline & 1) & 2) & 3) \\
\hline & CAPM & FF3 & FF5 \\
\hline \multirow[t]{2}{*}{ AQ factor } & $0.850^{* * *}$ & $0.312^{* * *}$ & $0.320^{* * *}$ \\
\hline & $(42.26)$ & $(4.82)$ & $(4.86)$ \\
\hline \multirow[t]{2}{*}{ RiskP } & $0.498^{\star * *}$ & $0.592^{* * *}$ & $0.599^{* * *}$ \\
\hline & $(24.60)$ & $(49.22)$ & $(48.67)$ \\
\hline \multirow[t]{2}{*}{ SMB } & & $0.0587^{\star *}$ & $0.0924^{\star *}$ \\
\hline & & $(2.74)$ & $(2.96)$ \\
\hline \multirow[t]{2}{*}{ HML } & & $-0.547^{\star * *}$ & $-0.570^{* * *}$ \\
\hline & & $(-15.29)$ & $(-15.40)$ \\
\hline \multirow[t]{2}{*}{ RMW } & & & 0.131 \\
\hline & & & $(1.84)$ \\
\hline \multirow[t]{2}{*}{ CMA } & & & $0.161^{\star * *}$ \\
\hline & & & $(3.83)$ \\
\hline \multirow[t]{2}{*}{ _cons } & $0.00758^{\star * \star}$ & $0.00856^{* * *}$ & $0.00795^{* * *}$ \\
\hline & (16.68) & $(21.56)$ & $(15.84)$ \\
\hline $\mathrm{N}$ & 4549 & 4549 & 4549 \\
\hline
\end{tabular}

Table 3. Fund managers' skill.

\begin{tabular}{ccccccc}
\hline & \multicolumn{3}{c}{ FF3 R $^{2}$} & & \multicolumn{3}{c}{ FF5 R } & \\
\hline Skill-level & high & mid & low & high & mid & low \\
\hline exc_return & 0.0087 & 0.00661 & 0.0011 & 0.00891 & 0.000794 & 0.00635 \\
FF3 & 0.00949 & 0.0083 & 0.00421 & 0.00987 & 0.00797 & 0.00377 \\
FF5 & 0.00913 & 0.00793 & 0.00324 & 0.00954 & 0.00759 & 0.00271 \\
\hline
\end{tabular}

size of the excess return.

This paper founds that, 1) the fund manager can effectively use the accrual quality information, and at the fund level, the accrual quality is a risk-pricing factor, and the fund manager can obtain excess returns through an accrual strategy; 2) fund managers' selecting stock ability is different. This difference is reflected in fund accrual quality risk premium. Good skilled fund managers are more able to get excess returns than poor skilled managers.

\section{References}

[1] Leuz, C. and Verrecchia, R.E. (2004) Firms' Capital Allocation Choices, Information Quality, and the Cost of Capital. SSRN Electronic Journal.

[2] Ali, A., Chen, X., Yao, T. and Yu, T. (2008) Do Mutual Funds Profit from the Accruals Anomaly? Journal of Accounting Research, 46, 1-26.

https://doi.org/10.1111/j.1475-679X.2007.00263.x 
[3] Amihud, Y. and Goyenko, R. (2013) Mutual Fund's r2 as Predictor of Performance. Review of Financial Studies, 26, 667-694. https://doi.org/10.1093/rfs/hhs182

[4] Ogneva, M. (2008) Accrual Quality, Realized Returns, and expected Returns: The Importance of Controlling for Cash Flow Shocks. Social Science Electronic Publishing, 87, 1415-1444.

[5] Francis, J., Lafond, R. and Schipper, K. (2004) Costs of Equity and Earnings Attributes. Accounting Review, 79, 967-1010. https://doi.org/10.2308/accr.2004.79.4.967

[6] Francis, J., Lafond, R., Olsson, P. and Schipper, K. (2005) The Market Pricing of Accruals Quality. Journal of Accounting \& Economics, 39, 295-327. https://doi.org/10.1016/j.jacceco.2004.06.003

[7] Bushee, B.J. and Raedy, J.S. (2006) Factors Affecting the Implementability of Stock Market Trading Strategies. SSRN Electronic Journal.

[8] Grossman, S.J. and Stiglitz, J.E. (1980) On the Impossibility of Informationally efficient Markets. Social Science Electronic Publishing, 70, 393-408.

[9] Kacperczyk, M. and Seru, A. (2007) Fund Manager Use of Public Information: New Evidence on Managerial Skills. Journal of Finance, 62, 485-528. https://doi.org/10.1111/j.1540-6261.2007.01215.x

[10] Chen, H.L., Jegadeesh, N. and Wermers, R. (2000) The Value of Active Mutual Fund Management: An Examination of the Stockholdings and Trades of Fund Managers. Journal of Financial \& Quantitative Analysis, 35, 343-368. https://doi.org/10.2307/2676208

[11] Berk, J.B., Green, R.C. and Naik, V. (2004) Valuation and Return Dynamics of New Ventures. Review of Financial Studies, 17, 1-35. https://doi.org/10.1093/rfs/hhg021

[12] Baker, M., Litov, L., Wachter, J.A. and Wurgler, J. (2010) Can Mutual Fund Managers Pick Stocks? Evidence from Their Trades Prior to Earnings Announcements. Journal of Financial \& Quantitative Analysis, 45, 1111-1131. https://doi.org/10.1017/S0022109010000426

[13] Grinblatt, M. and Titman, S. (1989) Mutual Fund Performance: An Analysis of Quarterly Portfolio Holdings. Journal of Business, 62, 393-416. https://doi.org/10.1086/296468

[14] Ferson, W. and Khang, K. (2002) Conditional Performance Measurement Using Portfolio Weights: Evidence for Pension Funds. Journal of Financial Economics, 65, 249-282. https://doi.org/10.1016/S0304-405X(02)00140-X 